\title{
Public knowledge and attitudes regarding children with disabilities, their experience and support in Bhutan: a national survey.
}

\author{
Abstract: Data were collected from heads of households across Bhutan, using a \\ Knowledge, Attitudes and Practices method to gain insights regarding children \\ with disabilities up to 18 years in Bhutan. Fieldwork was conducted by local \\ enumerators, trained by researchers from the UK who undertook the analysis and \\ interpretation of the data. Results indicate that whilst there are largely positive \\ attitudes towards children with disabilities in Bhutan, the majority of respondents \\ conceptualised disability narrowly and were pessimistic about such children's \\ ability to lead full lives. Households including children with disabilities were less \\ positive than others concerning the ways in which children are regarded and \\ supported in their communities. Fatalistic views related to beliefs in karma were \\ seen to persist and influenced expectations regarding what children with \\ disabilities might achieve. More positive attitudes are held by younger people and \\ those who are more highly educated. Attitudes and expectations have had a \\ negative effect in restricting access to educational and social inclusion for many \\ children with disabilities.
}

Keywords: Bhutan; disability; households; attitudes

Funding: This research was funded by the United Nations' Children's Fund and carried out under UNICEF Bhutan Institutional Contract No.43183260.

\section{Introduction}

Bhutan is a small Himalayan state, with a population of about 800,000 (United Nations, 2017). It is identified by the United Nations as a Least Developed Country (United Nations, 2017) with a strongly agrarian economy. Mahayana Buddhism is the state religion, followed by the majority of the population and considered the nation's spiritual heritage (National Council of Bhutan, 2008), though the constitution permits freedom of religion, and there is a sizeable Hindu minority in the south of the country. The country has undergone significant change over recent years. In 1999, it became one of 
the last nations to allow citizens access to television and the internet, which were previously banned. Political reforms have led to the country becoming a constitutional monarchy. Government policy across all areas is informed by the concept of Gross National Happiness, foregrounding factors such as economic equity, cultural and environmental preservation, and transparency in governance (Hofmann, 2006; Walcott, 2011).

Improving health, welfare and education for all, including children and young people with disabilities, is enshrined in recent Bhutanese legislation including the National Policy on Special Educational Needs (Ministry of Education, 2012) and the Child Care and Protection Act (Parliament of the Kingdom of Bhutan, 2011). Work is ongoing to develop a National Policy for Persons with Disabilities (Gross National Happiness Commission Secretariat, 2018). Children with disabilities are increasingly being educated in inclusive settings. The Bhutan Education Blueprint 2014-2024 (Ministry of Education, 2014) acknowledges the challenges faced regarding resources, facilities and expertise; nonetheless progress has been noted both in schools (Subba et al., 2018) and health services (Thinley et al., 2017).

It is however identified that further action is required to support social inclusion (Barnes and Sheldon, 2010; Schiemer, 2017; UNICEF, 2013a). Understanding current perceptions and beliefs regarding children with disabilities is a crucial step in developing appropriate strategies. Schuelka (2012) suggests that a challenge for Bhutan is to be seen to respond to international initiatives and documents expecting action towards achieving greater equity in education. Whilst responses may result in a focus upon educational shortcomings - and lead to the development of policy - there is often 
a significant gap between the written policy and implementation. Moreover, those required to deliver change in schools may be left behind in this process. The situation is further complicated by a general lack of understanding concerning disability and how this might be most appropriately supported within the country. Kamenopoulou and Dukpa (2018) interviewed teachers from across Bhutan and suggest that the 'medical model' of disability remains dominant. They further identify that many teachers are conflicted regarding the education of children with disabilities. There is a lack of understanding about the meaning of inclusion, and many teachers feel that educating children with disabilities requires specialist knowledge, currently unavailable in the country.

In January 2018 the Bhutanese Government issued a draft policy for persons with disabilities (Gross National Happiness Commission Secretariat, 2018). In acknowledging that such individuals often remain excluded from many aspects of life within the country, including access to education, the policy's authors identified four key areas - Non-discrimination, Diversity and Inclusiveness, Disability Mainstreaming and Participation. These are intended to provide foundations for immediate action and future development. The draft policy recognises that:

"Lack of education and marketable vocational training for children and youth with disabilities results in a lack of opportunities for further personal development and increases their marginalization and vulnerability”. (page 5)

Recommendations are made for increasing access to all educational facilities, realigning teacher education to ensure a more competent work force, and ensuring schools have appropriate staffing levels and teachers who are knowledgeable about special 
educational needs and disability issues. Whilst the implementation timetable for this policy has not been defined, it is clear that national policy makers are endeavouring to address the recommendations of the International Convention on the Rights of Persons with Disabilities (United Nations, 2007) to which the Bhutanese government is a signatory.

Research was undertaken by the authors on behalf of the United Nations Children's Fund and the Royal Government of Bhutan Ministry of Education (Ministry of Education/UNICEF, 2017). The purpose of this study was to better understand perceptions and beliefs regarding children with disabilities among the Bhutanese population. The term 'children with disabilities' refers to children up to the age of 18 with "long-term physical, mental, intellectual, or sensory impairments which in interaction with various barriers may hinder their full and effective participation in society on an equal basis with others" (United Nations, 2007, Article 1). Following a contextualised literature review (authors, 2019), a nationwide survey and a series of stakeholder focus groups were carried out. This paper reports and reflects upon the nationwide survey and its findings.

\section{Method}

Quantitative data were collected from heads of households across Bhutan during October 2016 using a structured questionnaire. Results were recorded on electronic tablet devices by local Bhutanese enumerators. Data cleansing and initial analysis were undertaken at the authors' institution at the end of 2016. 


\section{Data collection}

Data were collected via a semi-structured questionnaire. Enumerators visited households in 9 dzongkhags within Bhutan and completed the survey tool with the respondent in situ using an electronic tablet. The survey tool and sampling strategy underwent a number of iterations in response to comments and suggestions from UNICEF, the Bhutanese Ministry of Education, the project's reference group and the Bhutanese Research Ethics Board of Health.

\section{Data collection tool}

An eleven-page household survey questionnaire was developed to gather demographic information regarding respondents. This used both closed and open questions to gather data concerning their knowledge, attitudes and practices (KAP) regarding children with disabilities. Reference to previous KAP studies informed the design (e.g. Lakham and Sharma, 2010). A Likert scale gathered attitudinal data across five domains: society and support, personal attitude to disability, contribution made by children with disabilities, education and inclusion, and protection. It was intended that data would be collected regarding the composition of respondents' households; however, the enumerators in the field collected data regarding only the respondent and one other person in each household. This fact was identified only at the data analysis stage, after all data were collected). Where families included a child with disabilities, demographic data were collected regarding these children.

\section{Sample}

A stratified multistage sampling design (Roy, Acharya and Roy, 2016) was adopted, utilising an updated version of the 2005 Population and Housing Census of Bhutan 
(Office of the Census Commissioner, 2005) as a sampling frame. The country (composed of 20 dzongkhags - the primary administrative districts in Bhutan) was stratified into three regions (western, central and eastern) based on number of households and geographical location and nine dzongkhags - three in each region were selected for the study. These were Chhukha, Punaka and Thimpu in the west; Bumthang, Tsirang and Zhemgang in the centre; and Mongar, Pema Gatshel and Trashigang in the east. A number of gewogs (smaller administrative subdivisions) were then selected within each dzongkhag. Finally, individual households were indentified for inclusion.

Piloting was undertaken in two locations - one urban and one rural - within the Thimpu dzongkhag. Local enumerators conducted the pilot, supported by a local supervisor and accompanied by authors, as well as UNICEF and Bhutanese officials. Following the pilot, challenges identified were addressed in advance of data collection.

In total, 577 households were surveyed. Two incomplete questionnaires were deleted from the dataset, thus the final sample comprises 575 households. Just over a third of respondents ( $\mathrm{n}=198,34.4 \%$ ) lived in urban households, while just under two thirds $(n=378,65.6 \%)$ lived in rural households, reflecting the overall national urban/rural ratio. The geographical location of respondents by dzongkhag and gewogis shown in Table 1.

TABLE 1 ABOUT HERE 


\section{Demographic information about sample}

\section{$\underline{\text { Gender, religion and age }}$}

Of the 575 respondents, $488(84.8 \%)$ identified themselves as head of household. Two hundred and twelve respondents (36.9\%) were male, $363(63.1 \%)$ were female. The overwhelming majority were Buddhist ( $\mathrm{n}=556,96.7 \%)$, with a small number of Hindus $(n=17,3 \%)$, one Christian and one atheist. Most respondents were married $(n=457$, 79.5\%). Mode age of respondents was 42 years, mean age 44 years, $\mathrm{SD}=14.0$ (see Table 2).

\section{TABLE 2 ABOUT HERE}

\section{Education}

Mean length of time in education of respondents was 4 years. Over $60 \%$ of respondents had received no formal education $(n=348)$, and in total, $44.3 \%$ of males and $70 \%$ of female respondents had received no formal education. These percentages are considerably higher than suggested by the Bhutanese Living Standards Survey (National Statistics Bureau, 2017) where it is identified that $36 \%$ of males and $47 \%$ of females had received no formal education. Thirty-six respondents (6.2\% of the sample) held a bachelor's or post-graduate degree; of these, $36.1 \%(n=13)$ were women.

\section{Employment and income}

Respondents were employed in a range of occupations. Farming/other skilled agricultural work was most common $(\mathrm{n}=185,32.1 \%)$. Other frequently identified occupational statuses were housewife $(n=140,24.3 \%)$, self-employed $(n=105,18.2 \%)$ professional $(n=63,10.9 \%)$ and service/sales $(n=34,5.9 \%)$. Mean gross household 
income from all sources (including religious fees) was 174,220 Ngultrum (\$2590). Almost half $(n=285,49.6 \%)$ had an annual gross household income below 100,000 Ngultrum (\$1490).

\section{Families with children with disabilities}

Previous research identified that over $21 \%$ of Bhutanese children aged two to nine years have a disability (National Statistics Bureau et al., 2012). In the current study, only 17 households ( $3 \%$ of the sample) included children with disabilities: eight with boys and nine with girls. Sixteen were from rural areas, one from urban Thimphu. The age range of children with disabilities was two to 17 years. Over half had difficulties in multiple areas of functioning.

Just under half these children $(n=7)$ attended their local school; the same number $(n=7)$ were not in education and their mother $(n=5)$ or grandmother $(n=1)$ stayed at home to look after them during the day. Fourteen played with other children within their family, 13 played with other children outside the family, 11 visited their friends' homes to play, whist two played with friends only at school.

No respondents felt the child would be living outside the family household at age 18, either independently or with support. All identified the family as their main source of support, with further support identified from medical professionals $(n=7)$, school $(n=1)$ and neighbours $(\mathrm{n}=1)$. The majority $(\mathrm{n}=14,82.4 \%)$ felt they received insufficient support. Only 4 respondents $(23.5 \%)$ knew of another family that included a child with disabilities. 


\section{Results}

In this section results are presented regarding the whole sample, identifying respondents' knowledge and attitudes regarding children with disabilities.

\section{Knowledge regarding children with disabilities}

What comprises disability?

Respondents were asked to identify conditions they regarded as comprising a disability. A very high majority ( $>90 \%$ ) believed individuals who had a total loss of vision, total loss of hearing or who used a wheelchair had a disability. Slightly fewer considered those who had conditions limiting the use of their hands or who needed a walking aid to have a disability. Fewer than two thirds considered individuals who used hearing aids as disabled while slightly more than half considered low vision or learning difficulties as disabilities (see Table 3).

\section{TABLE 3 ABOUT HERE}

Legislation, services and information

Ninety-four respondents (16.3\%) stated they were aware of Bhutanese legislation regarding children with disabilities; however, few could identify any by name. Over a third $(n=203,35.3 \%)$ were aware of services, and spoke of aids, health provision, educational provision, financial support and kidu (social welfare provided locally and supported by the monarchy) (Shaw, 2015). Specific organisations, foundations and institutes were identified by name by a small number of respondents. Only four of the 17 families with children with disabilities were aware of any Bhutanese legislation regarding such children; and only two were aware of any local specialist services. 
Whilst a majority of respondents were aware that generic educational and health services provided support to families with children with disabilities, only a small minority knew of social protection services $(n=152,26.4 \%)$, child protection services $(n=157,27.3 \%)$ or related legislation $(n=58,10.1 \%)$. Few knew of local support groups or organisations $(\mathrm{n}=83,14.4 \%)$; slightly more were aware of religious groups that provided support $(\mathrm{n}=93,16.2 \%)$. Only 114 respondents $(19.8 \%)$ were aware of referral systems for children with disabilities and their families.

Concerning information about disability, over $80 \%$ of respondents identified television as their primary source of information $(n=466,81 \%)$. Friends $(n=299,52 \%)$, neighbours $(n=243,42.3)$, family $(n=214,37.2 \%)$ and the radio $(n=204,35.5 \%)$ were the next most important sources. Given the Bhutanese adult literacy rate of about $60 \%$ (National Statistics Bureau, 2017) it is perhaps unsurprising that newspapers are less influential $(n=72,12.5 \%)$ than these other sources.

\section{Attitudes regarding children with disabilities}

Respondents were asked to rate statements regarding disability across five domains. A seven-point Likert Scale was used to gauge opinion (Strongly agree, Agree, Slightly Agree, Neither Agree nor Disagree, Slightly Disagree, Disagree, Strongly Disagree). An eighth 'Don't know' category was also provided, to allow for situations where respondents felt uninformed. For the purposes of reporting here, this was simplified into four categories: Agree (all degrees of agreement added together), Neither Agree nor Disagree, Disagree (all degrees of disagreement added together) and Don't Know (See Table 4). Comparisons are drawn between families including children with disabilities 
$(n=17)$ and those without $(n=558)$ disabilities: however, the caveat is given that as this first group is so small, statistical inferences are inappropriate.

\section{TABLE 4 ABOUT HERE}

\section{Responses regarding society and support}

Respondents' attitudes regarding societal attitudes and support were overwhelmingly positive concerning the situation in Bhutan. Over three-quarters felt children with disabilities were treated fairly in society in general $(n=447,77.7 \%)$ and within their local communities ( $\mathrm{n}=471,81.9 \%$ ). Almost $90 \%$ felt attitudes towards children with disabilities had improved over the last decade $(n=515,89.6 \%)$, and that life was now better for such children and their families $(\mathrm{n}=502,87.3 \%)$. Whilst almost all acknowledged that children with disabilities needed extra support $(n=564,98.1)$, over $85 \%$ felt the benefits and support provided by the state were adequate $(n=499,86.8 \%)$. Households including children with disabilities, however, were less positive than those without concerning the treatment of and attitudes to children with disabilities. Though there was agreement that things were better than in earlier times fewer than $60 \%$ of families with children with disabilities felt the level of state support was sufficient.

\section{Responses regarding personal attitudes to disability}

Negative attitudes towards disability were shown by a large minority of respondents: Over half $(n=316,55 \%)$ felt children with disabilities could not lead full lives. Over $40 \%(n=246,42.8 \%)$ said they would be unhappy to have a child with disabilities living next door. A third ( $n=191,33.2 \%)$ reported that they would be unhappy if their child married a person with disabilities. Respondents were more positive towards children 
with disabilities attending the same class as their children $(n=407,70.1 \%)$. A protective and paternalistic attitude towards disability was evidenced, with over $90 \%$ considering it appropriate to treat such children more favourably than others $(n=518,90.1 \%)$.

There was high agreement with the statement that children's disabilities are the result of past deeds $(\mathrm{n}=476,82.8 \%)$. This was true both for parents of children with disabilities and those without, and seemingly contradicts Schuelka's assertion (2015) that disability is now seen as a result of medical factors rather than karma, particularly among parents of such children.

Responses regarding the contribution made by children with disabilities

Negative attitudes towards children with disabilities were again evident in this domain, with almost $20 \%$ of respondents believing they did not contribute positively to their family $(\mathrm{n}=111,19.3 \%)$. An even higher proportion stated that such children did not contribute positively to society $(n=138,24 \%)$. Again, there was high congruence between families with and without such children.

\section{Responses regarding education and inclusion}

There was almost universal agreement that children with disabilities benefit from attending school $(n=567,98.6 \%)$, that all children should attend school $(n=561,97.6 \%)$ and that schools are better able to support such children than a decade ago $(n=519$, 90.3\%). Over three-quarters agreed that children with disabilities should be supported and encouraged to play with their non-disabled peers $(n=454,79 \%)$ and that they should have the same employment opportunities as these peers when they left school $(n=436$, $75.8)$. 
Two questions about educational inclusion led to contradictory responses. A question about whether children with disabilities should attend the same school as others led to a balanced response, with similar numbers saying yes $(n=287,49.9 \%)$ and no $(n=273$, 47.5\%). However, responding to a question about whether children with disabilities should attend special schools, a clear majority $(n=510,88.7 \%)$ answered yes. Previous research in Bhutan has revealed contradictory attitudes regarding inclusion (Chhetri, 2015; Kamenopoulou and Dukpa, 2018; Thuji, 2013). Studies elsewhere have also noted how educators may hold contradictory views regarding inclusion (Male, 2011; Ross-Hill, 2009) and Bhutanese responses may suggest a more general societal contradiction regarding inclusion. Responses were similar between households with and without children with disabilities.

\section{Responses regarding the protection of children with disabilities}

Research and personal accounts across the world have long identified that individuals with disabilities are at risk of stigmatisation (Susman, 1994), and that disabled children are at heightened risk of a spectrum of abusive behaviours (Sobsey, 2014; Stalker and McArthur, 2012). Moreover Schuelka (2015) has identified evidence in Bhutan of children with disabilities experiencing stigmatisation, including mockery and namecalling. Almost $60 \%$ of respondents acknowledged such children were at heightened risk of bullying $(n=344,59.8 \%)$ or physical and sexual abuse $(n=319,55.5 \%)$. However, fewer than half agreed they were more likely than others to suffer neglect $(n=260$, $45.2 \%$ ) and fewer than a third of respondents felt they might be the subject of jokes or unacceptable comments $(\mathrm{n}=182,31.7 \%)$. 
Paternalistic attitudes were revealed in two further responses in this domain. Over $60 \%$ of respondents $(n=352,61.2 \%)$ disagreed with the statement that it might sometimes be necessary or appropriate to punish a child with disabilities for misbehaviour, and over $80 \%(\mathrm{n}=480,83.5 \%)$ felt that it would be inappropriate ever to leave such a child at home alone. Households including children with disabilities were more likely to acknowledge that disabled children might be bullied, or that it could be appropriate to sometimes punish such children, but again there was high congruence.

\section{Differences between subgroups}

Bhutanese governmental initiatives over many years, such as the 'One Nation, One People' proviso of 1989, have been designed with cultural and social homogeneity as an explicit aim (Schmidt, 2017; Walcott, 2011). The challenges that these have created for minority populations within Bhutan, and the impact of these initiatives upon them, should not be minimised (Carrick, 2008; Kharat, 2001; Meier and Chakrabarti, 2016). Nonetheless, the results of this survey exhibit a high level of congruence and that no statistically significant differences were noted between, e.g. responses of males or females, or between residents of urban or rural areas. However, statistically significant differences were noted when comparisons were drawn between respondents by age and educational status. These are discussed below.

\section{Comparison of responses by age}

Respondents were considered within 3 sub-sets: younger respondents under 40 years $(n=254)$, middle-aged respondents $40-59$ years $(n=239)$, and older respondents aged 60 years and above $(n=82)$. Statistically significant differences were identified regarding seven statements across all five attitudinal domains (see Table 5). 


\section{TABLE 5 ABOUT HERE}

Regarding the statement that attitudes towards children with disabilities were better than they were ten years ago, middle-aged respondents expressed higher agreement than either younger or older respondents. Concerning personal attitudes, older respondents were less positive about having a family with a child with disabilities as neighbours than the two younger groups. With regard to the contribution made by children with disabilities, older respondents were again less positive than the two younger groups. Older respondents were by contrast more positive than the two younger groups that schools were better equipped and prepared to deal with inclusion than a decade ago.

There were statistically significant differences between the three sub-sets regarding three statements regarding child protection. While about two thirds of the two younger groups disagreed with the statement that children with disabilities were the subject of jokes or unacceptable and negative comments, older respondents were much more equivocal. By contrast, younger respondents were in greater agreement that children with disabilities were at a heightened risk both of bullying and physical or sexual abuse.

\section{Comparison of responses by education level}

To explore whether education level impacted upon attitudes towards children with disabilities, the responses of the least-educated subset of the sample - those who had received no formal education $(n=348,60.5 \%)$ - were compared with those of the most highly educated - the 36 individuals $(6.2 \%)$ educated to degree or postgraduate level (see Table 6). No significant differences were identified in domains relating to society 
and support or protection. However, significant differences were identified regarding nine statements across the other three domains.

\section{TABLE 6 ABOUT HERE.}

Regarding personal attitudes, there were statistically significant differences between the groups concerning five of the six statements. More highly educated respondents were much more positive about a family including a child with a disability being their neighbour, with $77.7 \%$ stating they would be happy with this, as opposed to fewer than half $(48.6 \%)$ of those with no formal education. They were also more positive about a child with disabilities attending the same class as their own: almost $90 \%$ would be happy with this, compared to just over two thirds of those without formal education.

More highly educated respondents were also more positive regarding the ability of children with disabilities to lead a full life. Half this group disagreed with the statement that 'Children with disabilities cannot lead as full a life as those without disabilities', compared to fewer than $30 \%$ of those without formal education. A more mixed picture emerged concerning the statement that 'In the future, I would be happy for my child to marry a person with disabilities'. While about half of both groups agreed with the statement, a greater number of more highly educated respondents admitted to uncertainty (16.7\% compared to $1.4 \%)$.

There were highly significant differences with regard to attitudes regarding causation of disability. Over $85 \%$ of those without formal education agreed this was the result of past deeds, whereas only slightly over half of the highly-educated group felt this to be the 
case. With respect to the contribution made by children with disabilities, more highly educated respondents were again more positive. Only 5.6\% disagreed with the statement that 'children with disabilities make a positive contribution to the family' (compared with 19.5\%); and over $83.3 \%$ felt such children make a contribution to society (compared with 55.2\%). Highly-educated respondents were more sceptical concerning schools being better prepared/equipped to deal with children with disabilities than ten years ago. Just under $70 \%$ considering schools to be better prepared, compared to over $90 \%$ of those with no formal education. More highly educated respondents also felt more strongly that such children should be encouraged and supported to play with non-disabled peers, with only just over $5 \%$ of respondents disagreeing, compared with almost $20 \%$ of those without formal education.

\section{Discussion}

The data secured in this study point to several emergent themes in respect of childhood disability issues in Bhutan. Whilst data limitations require that these findings should be treated with some caution, they nonetheless highlight several areas which will be worthy of more detailed scrutiny.

The study, the first of its kind with regard to this country, has revealed much regarding knowledge and attitudes regarding disabled children in Bhutan. Overall, despite the initiatives undertaken by the Bhutanese government and external organisations such as UNICEF, knowledge regarding children with disability, services and legislation was limited. Disability is relatively narrowly conceptualised, with an emphasis on overt physical or sensory impairment. These are the conditions that are societally recognised, and it is services for such individuals - such as the Muenselling Institute in Khaling and 
the Wangsel Institute in Paro, that were identified by the heads of households who were the survey respondents. Individuals with less obvious or severe impairments - such as low vision or poor hearing - were not considered disabled by a large minority of respondents; and almost half did not consider intellectual impairment to be a disability. The literature has long identified the negative impact that such attitudes can have for those with less obvious disabilities (Cavet, 1998) while Parmenter (2008) warns of the potential for those with intellectual impairments to be marginalised and stigmatised in settings where services are limited.

The study illustrated that attitudes towards children with disabilities within Bhutan display a high level of homogeneity and are typified by paternalistic assumptions of incapacity and dependence (UNICEF, 2013b). As has long been identified in the global West, more positive attitudes regarding those with disabilities are held by younger people and those who are more highly educated (Morin, Rivard, Crocker, Boursier and Caron, 2013; Strohmer, Grand and Purcell, 1984; Yazbeck, McVilly and Parmenter, 2004). This highlights the importance of improving education for all in order to bring about more effective social and educational inclusion for children with disabilities through the successful implementation of initiatives such as the Bhutan Education Blueprint (Ministry of Education, 2014).

There is some suggestion that the ongoing challenges in meeting the needs of children with disabilities and the responses forthcoming within Bhutan have wider parallels in many other national settings, irrespective of their stage of development. This linkage may prove a useful device, offering illustrations of social and educational policy responses to the challenges posed. Of note amongst these is the current trend to attempt 
a systems-based resolution by adopting an ecological approach to service provision (Mackelprang and Salsgiver, 2015). The adoption of this approach is made essential because of the complexity of inter-related factors informing childhood disability, wellillustrated in the Bhutanese data presented in this paper. These mirror the complex interactions between individuals, agencies and their interpretations of existing legislation, and the impact of cultural values, as well as some awareness by nonprofessionals that children with disabilities require additional support from diverse sources. Moreover, these data suggest that effective dissemination of credible and userfriendly knowledge makes whole-community approaches essential to moving forward from policy to action.

In respect of progressing a change agenda for children with disabilities, a major obstacle appears to be that public attitudes to disability are mainly based on an understanding that 'disability' is predominantly related to physical functioning and well-being (rather than cognitive/learning difficulties). In this respect, access to credible, authoritative and audience-friendly information about disability might provide an important catalyst for attitudinal change.

A further important theme emerging from the data generated is that parents of children with disabilities report many of the challenges identified in the current literature on disability in diverse international settings elsewhere (WHO, 2011). About half of the children in the study, for instance, are not being educated in school; families seem to adopt a protective approach, given the incidence, noted in these data, of bullying towards children with disability. The families themselves can also be isolated from the supportive network provided by other families in a similar position. Furthermore, there 
is a growing body of empirical evidence from across the world indicates that "people with disabilities and their families are more likely to experience economic and social disadvantage than those with-out disability' (WHO, 2011, p.10). This places a significant additional burden on their efforts to support family members with disabilities. It is noticeable, however, that the study's findings correlate with research reported extensively in the literature, which indicate that these families themselves are often the most knowledgeable about disability issues.

The present study secured some initial indications that there was a willingness amongst educational professionals to engage with issues presented by the exclusion of children with disabilities from school and social settings. Whilst direct engagement with schools was not a focus for data generation, anecdotal narrative evidence from informal conversations with teachers suggested a growing awareness of the need to provide disability-related professional development for key personnel working with children with disabilities. However, further focused research efforts would be required to gain an in-depth picture of the current position regarding practice in formal education settings for such children, thereby realising substantive and useful detail of their experiences in such settings. Further limitations are the small number of families with children with disabilities included in the sample, and the religious homogeneity of the sample (Buddhists made up almost $97 \%$ of the sample, while they comprise about $75 \%$ of the total population).

\section{Conclusions}

The challenges associated with levels of understanding and attitudes towards the inclusion of children with disabilities in mainstream education seen in Bhutan, are 
similar to those reported from elsewhere in South Asia (Lakhan and Sharma, 2010). Marginalisation of individuals with special educational needs or disabilities has been highlighted as an issue of concern by several writers from the region (Shah, Das, Desai and Tiwari, 2013; Lamichhane and Okubo, 2014). It is suggested by these researchers that students with disabilities are driven to the margins of their communities as a result of the low expectations of academic achievement which is to be found in many schools (Singh Kainth, 2014; Rose and Malkani, 2019). This is particularly the case where geographical factors have presented difficulties in terms of accessing schools (Begum et al., 2019), as may be seen in much of Bhutan. In addition, the influence of religious beliefs upon perceptions of disability such as those witnessed in Bhutan (Kamenopulou and Dukpa, 2018) have been seen to impact upon teacher attitudes and expectations in other countries (Klibthong, 2013; Kim, Lu, and Estrad-Hernandez, 2013).

Where negative attitudes and low expectations persist this invariably impacts classroom practice (Hodkinson and Devarakonda (2009) a situation which is exacerbated where opportunities for gaining skills and understanding through initial teacher education and the professional development of serving teachers, are limited as has been reported from several countries in South Asia (Saravanabhavan and Saravanabhavan, 2010; Das, Gichuru and Singh 2013).

\section{Acknowledgements}

As identified above, this research was funded by UNICEF: this does not imply endorsement by UNICEF of the views expressed. The opinions expressed are those of the authors and do not necessarily reflect the policies or views of UNICEF. Sincere 
thanks are extended to Sonam Tshering at Bhutan Interdisciplinary Research and Development for his expertise and support in carrying out this study.

\section{Declaration of interest statement}

No authors have any conflict of interest.

\section{References}

Barnes, C., \& Sheldon, A. (2010). Disability, politics and poverty in a majority world context. Disability \& Society, 25(7), 771-782.

Begum, H, A., Perveen, R., Chakma, E., Dewan, L., Afroze, R,S, \& Tangen, D. (2019) The challenges of geographical inclusive education in rural Bangladesh, International Journal of Inclusive Education, 23 (1), 7-22.

Carrick, B. (2008) The rights of the Nepali minority in Bhutan. Asia-Pacific Journal on Human Rights and the Law, 9(1), 13-28.

Cavet, J. (1998) People Don't Understand: children, young people and their families living with a hidden disability. London: National Children's Bureau.

Chhetri, K.K. (2015) Investigating Teachers' Concerns and Experiences in Teaching Children with Special Educational Needs in Bhutan. Unpublished MA dissertation. Brisbane: Queensland University of Technology.

Das, A.K., Gichuru, M, \& Singh, A. (2013). Implementing inclusive education in Delhi, India: regular school teachers' preferences for professional development delivery modes. Professional Development in Education, 35, (9), 698-711.

Authors (2019) Knowledge, attitudes and practices to children with disabilities in Bhutan: a contextualised literature review (in press, $\mathrm{xxxxxxxxxxx).}$ 
Gross National Happiness Commission Secretariat (2018) National Policy for Persons with Disabilities. First Draft - January 2018. Thimpu: Gross National Happiness Commission Secretariat.

Hodkinson, A, \& Devarakonda, C. (2009). A critical examination of the perspectives and practices of teachers in India. Research in Education, 82 (1), 85-99.

Hofmann, K. (2006) Democratization from above: the case of Bhutan. Democracy International. Accessed 26 November 2018 at: http://www.democracyinternational.org/fileadmin/di/pdf/papers/di-bhutan.pdf

Kamenopulou, L. \& Dukpa, D. (2018) Karma and human rights: Bhutanese teachers' perspectives on inclusion and disability. International Journal of Inclusive Education, 22(3), 323-338.

Kharat, R.S. (2001) The ethnic crisis in Bhutan: its implications. India Quarterly: a Journal of International Affairs, 57(1), 39-50.

Kim, K, H., Lu, J, \& Estrada-Hernandez, N. (2015) Attitudes toward people with disabilities: the tripartite model, social desirability, and other controversial variables. Journal of Asia Pacific Counseling 5, (1), 1 - 15

Klibthong, S. (2013) Exploring Thai early childhood teachers' understanding, beliefs and concerns of inclusive education: a case study of an early childhood centre. MIER Journal of Educational Studies, Trends and Practices. 3, (1), 16 - 32

Lakhan, R, \& Sharma, M. (2010) a study of knowledge, attitudes and practices (KAP)survey of families toward their children with intellectual disability in Barwani, India. Asia Pacific Disability Rehabilitation Journal. 21, (2), 101 - 117 Lamichhane, K, \& Okubo, T. (2014) The Nexus between Disability, Education, and Employment: Evidence from Nepal, Oxford Development Studies, 42 (3), 439453, 
Mackelprang, R. \& Salsgiver, R. (2015) Disability. A Diversity Model Approach in Human Service Practice. Chicago: Lyceum Books

Male, D.B. (2011) The impact of a professional development programme on teachers' attitudes towards inclusion. Support for Learning, 26(4), 182-186.

Meier, B.M. \& Chakrabarti, A. (2016) The paradox of happiness: health and human fights in the Kingdom of Bhutan. Health and Human Rights Journal, 18(1), 193207.

Ministry of Education (2012) National Policy on Special Educational Needs. Thimpu: Royal Government of Bhutan.

Ministry of Education (2014). Bhutan Education Blueprint, 2014-2024: Rethinking Education. Thimphu: Royal Government of Bhutan.

Ministry of Education and UNICEF (2017) Knowledge, Attitudes and Practices (KAP) Study on Children with Disabilities. Thimpu: Royal Government of Bhutan/UNICEF.

Morin, D., Rivard, M., Crocker, A.G., Boursier, C.P. \& Caron, J. (2013) Public attitudes towards intellectual disability: a multidimensional perspective. Journal of Intellectual Disability Research, 57(3), 279-292.

National Statistics Bureau, Ministry of Education, Ministry of Health, UNICEF (2012) Two-Stage Child Disability Study among Children aged 2-9 years: Bhutan 2010-11. Thimpu: National Statistics Bureau.

National Statistics Bureau (2017) Bhutan Living Standards Survey Report. Thimpu: National Statistics Bureau.

Office of the Census Commissioner (2005) Population and Housing Census of Bhutan 2005. Thimpu: Office of the Census Commissioner. 
Parliament of the Kingdom of Bhutan (2011) Child Care and Protection Act. Thimpu: Parliament of the Kingdom of Bhutan.

Parmenter, T.R. (2008) The present, past and future of the study of intellectual disability: challenges in developing countries. Salud Pública de México, 50(supp. 2), S124-131.

Rose, R, \& Malkani, R. (2019) Policies and practices that foster education for all: Implications for economically poor nations. Oxford Research Encyclopedia of Education. New York: Oxford University Press

Ross-Hill, R. (2009) Teacher attitude towards inclusion practices and special needs students. Journal of Research in Special Educational Needs, 9(3), 188-198.

Roy, T.K., Acharya, R. \& Roy, A.K. (2016) Statistical Survey Design and Evaluating Impact. Cambridge: Cambridge University Press.

Saravanabhavan, S. \& Saravanabhavan, R. C. (2010) Knowledge of learning disability among pre- and in-service teachers in India. International Journal of Special Education, $25,(3), 132-138$.

Schiemer, M. (2017) Education for Children with Disabilities in Addis Ababa, Ethiopia, Inclusive Learning and Educational Equity 4. New York: Springer Open.

Schmidt, J.D. (2017) Development Challenges in Bhutan: Perspectives on Inequality and Gross National Happiness. New York: Springer.

Schuelka, M.J. (2012) Inclusive education in Bhutan: A small state with alternative priorities Current Issues in Comparative Education 15(1) 145-156.

Schuelka, M.J. (2015) The evolving construction and conceptualisation of 'disability' in Bhutan. Disability and Society, 30(6), 820-833. 
Shah, R., Das, A., Desai, I, \& Tiwari, A. (2013). Teachers' concerns about inclusive education in Ahmedabad, India. Journal of Research in Special Educational Needs, 16(1), 34-45.

Shaw, B.C. (2015) Notes concerning the political role of kidu. Journal of Bhutan Studies, 33 (Winter 2015), 1-22.

Singh Kainth, G. (2014), Adoption of RTE (Right to Education) in Private Schools of Rural Punjab. Amritsar: Guru Arjan Dev Institute of Development Studies.

Sobsey, D. (2014). Violence and disability. Accessed 15 November 2018 at: http://eugenicsarchive.ca/discover/encyclopedia/535eee9d7095aa0000000262

Stalker, K. \& McArthur, K. (2012) Child abuse, child protection and disabled children: a review of recent research. Child Abuse Review, 21(1),24-40.

Strohmer, D.C., Grand, S.A. \& Purcell, M.J. (1984) Attitudes toward persons with a disability: an examination of demographic factors, social context, and specific disability. Rehabilitation Psychology, 29(3), 131-145.

Subba, A.B., Yangzom, C., Dorji, K., Choden, S., Namgay, U., Carrington, S. \& Nickerson, J. (2018) Supporting students with disability in schools in Bhutan: perspectives from school principals. International Journal of Inclusive Education, online first. Accessed 20 November 2018 at: https://doi.org/10.1080/13603116.2018.1514744

Susman, J. (1994) Disability, stigma and deviance. Social Science and Medicine, 38(1), $15-22$.

Thinley, S., Tshering, P., Wangmo, K., Wangmo, K., Wangchuk, N. et al. (2017). The kingdom of Bhutan health system review. World Health Organization. Regional Office for South-East Asia 
Thuji, Z. (2013) Role of Civil Society Organizations in Inclusive Education

Development in Bhutan. Paper presented at the Regional Seminar on Inclusive

Education with focus on CWD, Paro College of Education, 3-5 December 2013.

Thimpu: Ability Bhutan.

UNICEF (2013a) Meeting the Educational Needs of Children with Disabilities in South

Asia: a gap analysis covering Bhutan and the Maldives. Kathmandu: UNICEF.

UNICEF (2013b) The State of the World's Children 2013: Children with Disabilities.

New York: UNICEF.

United Nations (2007) Convention on the Rights of Persons with Disabilities. New York: United Nations.

United Nations (2017) World Population Prospects: the 2017 Revision. New York:

United Nations Department of Economic and Social Affairs, Population Division.

Walcott, S.M. (2011) One of a kind: Bhutan and the modernity challenge. National Identities, 13(3), 253-265.

World Health Organisation (2011) World Report on Disability. Geneva: WHO

Yazbeck, M., McVilly, K. \& Parmenter T.R. (2004) Attitudes towards people with intellectual disabilities: an Australian perspective. Journal of Disability Policy Studies, 15(2), 97-111. 
Table 1 Location of households surveyed by dzongkhag

\begin{tabular}{|c|c|c|c|}
\hline Dzonhkgag & Gewog & No & $\%$ \\
\hline \multirow[t]{2}{*}{ Bumthang } & Urban: town $(\mathrm{n}=20)$ & \multirow[t]{2}{*}{40} & \multirow[t]{2}{*}{6.9} \\
\hline & Rural: Chumney (n=20) & & \\
\hline \multirow[t]{4}{*}{ Chukha } & Urban: town $(\mathrm{n}=40)$ & \multirow[t]{4}{*}{98} & \multirow[t]{4}{*}{17.0} \\
\hline & Rural: Bongo $(n=19)$ & & \\
\hline & Rural: Chapcha $(\mathrm{n}=19)$ & & \\
\hline & Rural: Phuntsholing $(n=20)$ & & \\
\hline \multirow[t]{2}{*}{ Mongar } & Urban: town $(n=20)$ & \multirow[t]{2}{*}{80} & \multirow[t]{2}{*}{13.9} \\
\hline & Rural: Mongar $(\mathrm{n}=60)$ & & \\
\hline \multirow[t]{3}{*}{ Pema Gatshel } & Urban: town $(n=20)$ & \multirow[t]{3}{*}{60} & \multirow[t]{3}{*}{10.4} \\
\hline & Rural: Shumar $(\mathrm{n}=20)$ & & \\
\hline & Rural: Zobar (n=20) & & \\
\hline \multirow[t]{3}{*}{ Punakha } & Urban: town $(\mathrm{n}=20)$ & \multirow[t]{3}{*}{60} & \multirow[t]{3}{*}{10.4} \\
\hline & Rural: Barp $(n=20)$ & & \\
\hline & Rural: Talo $(n=20)$ & & \\
\hline \multirow[t]{2}{*}{ Thimpu } & Urban: town $(\mathrm{n}=58)$ & \multirow[t]{2}{*}{78} & \multirow[t]{2}{*}{13.7} \\
\hline & Rural: Geney $(\mathrm{n}=20)$ & & \\
\hline \multirow[t]{5}{*}{ Trashigang } & Urban: town $(\mathrm{n}=20)$ & \multirow[t]{5}{*}{119} & \multirow[t]{5}{*}{20.7} \\
\hline & Rural: Bidung $(\mathrm{n}=20)$ & & \\
\hline & Rural: Kanglung $(\mathrm{n}=39)$ & & \\
\hline & Rural: Khaling $(\mathrm{n}=20)$ & & \\
\hline & Rural: Lumang $(\mathrm{n}=20)$ & & \\
\hline Tsirang & Rural: Mendrelgang $(n=20)$ & 20 & 3.5 \\
\hline Zhemgang & Rural: Trong $(n=20)$ & 20 & 3.5 \\
\hline TOTAL & & 575 & 100 \\
\hline
\end{tabular}


Table 2 Respondents by age

\begin{tabular}{|l|l|l|}
\hline Age & No & \% \\
\hline Under 20 yrs & 1 & 0.1 \\
\hline $20-29$ yrs & 83 & 14.4 \\
\hline $30-39$ yrs & 170 & 29.6 \\
\hline $40-49$ yrs & 124 & 21.6 \\
\hline $50-59$ yrs & 115 & 20.0 \\
\hline $60-69$ yrs & 49 & 8.5 \\
\hline $70-79$ yrs & 23 & 4.0 \\
\hline 80 yrs and over & 10 & 1.7 \\
\hline Total & 575 & 100 \\
\hline
\end{tabular}


Table 3 Statements regarding what comprises a disability $(n=575)$

\begin{tabular}{|l|l|l|}
\hline Statement & No & $\%$ \\
\hline A person/child who has a total loss of vision has a disability & 544 & 94.6 \\
\hline A person/child who has low vision and requires glasses has a & 290 & 50.4 \\
\hline $\begin{array}{l}\text { A person/child who has a total loss of hearing has a disability } \\
\text { disability }\end{array}$ & 537 & 93.4 \\
\hline A person/child who needs to use a wheelchair has a disability & 540 & 93.9 \\
\hline A person/child who needs to use a walking aid (such as a stick) has a & 447 & 77.7 \\
\hline disability & 369 & 64.2 \\
\hline A person/child who has a condition that limits the use of their hands & 500 & 87.0 \\
\hline A person/child who has difficulties with learning at the same pace as & 297 & 51.7 \\
\hline
\end{tabular}


Table 4 Responses to attitudinal statements $(n=575)$

\begin{tabular}{|c|c|c|c|c|c|c|c|c|}
\hline \multirow[t]{2}{*}{ Statement } & \multicolumn{2}{|c|}{ Agree } & \multicolumn{2}{|c|}{$\begin{array}{l}\text { Neither } \\
\text { agree nor } \\
\text { disagree }\end{array}$} & \multicolumn{2}{|c|}{ Disagree } & \multicolumn{2}{|c|}{$\begin{array}{l}\text { Don't } \\
\text { know }\end{array}$} \\
\hline & No & $\%$ & No & $\%$ & No & $\%$ & No & $\%$ \\
\hline \multicolumn{9}{|l|}{ Responses regarding society and support } \\
\hline $\begin{array}{l}\text { People in the local community have a } \\
\text { positive attitude towards children with } \\
\text { disabilities. }\end{array}$ & 471 & 81.9 & 36 & 6.3 & 61 & 10.6 & 7 & 1.2 \\
\hline $\begin{array}{l}\text { Children with disabilities are treated fairly in } \\
\text { society. }\end{array}$ & 447 & 77.7 & 24 & 4.2 & 93 & 16.1 & 11 & 1.9 \\
\hline $\begin{array}{l}\text { Attitudes towards children with disabilities } \\
\text { are better than they were ten years ago. }\end{array}$ & 515 & 89.6 & 32 & 5.6 & 13 & 2.3 & 15 & 2.6 \\
\hline $\begin{array}{l}\text { Life is better for children with disabilities } \\
\text { and their families than it was ten years ago. }\end{array}$ & 502 & 87.3 & 44 & 7.7 & 16 & 2.8 & 13 & 2.3 \\
\hline $\begin{array}{l}\text { Children with disabilities and their families } \\
\text { need extra support. }\end{array}$ & 564 & 98.1 & 4 & 0.7 & 7 & 1.2 & 0 & 0 \\
\hline $\begin{array}{l}\text { The state provides adequate benefits for } \\
\text { children with disabilities. }\end{array}$ & 499 & 86.8 & 21 & 3.7 & 42 & 7.3 & 13 & 2.3 \\
\hline \multicolumn{9}{|c|}{ Statements regarding personal attitudes to children with disabilities } \\
\hline $\begin{array}{l}\text { I would be happy to have a family with a } \\
\text { child with disabilities living next door to me. }\end{array}$ & 295 & 51.3 & 25 & 4.4 & 246 & 42.8 & 9 & 1.6 \\
\hline
\end{tabular}




\begin{tabular}{|c|c|c|c|c|c|c|c|c|}
\hline $\begin{array}{l}\text { I would be happy to have a child with } \\
\text { disabilities attending the same class as my } \\
\text { child. }\end{array}$ & 407 & 70.8 & 8 & 1.4 & 157 & 27.3 & 3 & 0.5 \\
\hline $\begin{array}{l}\text { In the future, I would be happy for my child } \\
\text { to marry a person with disabilities. }\end{array}$ & 313 & 54.4 & 55 & 9.6 & 191 & 33.2 & 16 & 2.8 \\
\hline $\begin{array}{l}\text { Children's disabilities are the result of past } \\
\text { deeds. }\end{array}$ & 476 & 82.8 & 24 & 4.2 & 69 & 12.0 & 6 & 1.0 \\
\hline $\begin{array}{l}\text { Children with disabilities cannot lead as full } \\
\text { a life as those without disabilities. }\end{array}$ & 316 & 55.0 & 55 & 9.6 & 190 & 33.0 & 14 & 2.4 \\
\hline $\begin{array}{l}\text { It is sometimes alright to treat children with } \\
\text { disabilities more favourably than other } \\
\text { children. }\end{array}$ & 518 & 90.1 & 18 & 3.1 & 38 & 6.6 & 1 & 0.2 \\
\hline \multicolumn{9}{|c|}{ Statements regarding contribution made by children with disabilities } \\
\hline $\begin{array}{l}\text { Children with disabilities make a positive } \\
\text { contribution to the family. }\end{array}$ & 379 & 65.9 & 67 & 11.7 & 111 & 19.3 & 18 & 3.1 \\
\hline $\begin{array}{l}\text { Children with disabilities contribute to } \\
\text { society. }\end{array}$ & 349 & 60.7 & 64 & 11.1 & 138 & 24.0 & 24 & 4.2 \\
\hline \multicolumn{9}{|l|}{ Statements regarding education and inclusion } \\
\hline $\begin{array}{l}\text { All children should go to school, regardless } \\
\text { of their needs or any disability. }\end{array}$ & 561 & 97.6 & 6 & 1.0 & 8 & 1.4 & 0 & 0 \\
\hline $\begin{array}{l}\text { Children with disabilities benefit from } \\
\text { attending school. }\end{array}$ & 567 & 98.6 & 4 & 0.7 & 3 & 0.5 & 0 & 0 \\
\hline
\end{tabular}




\begin{tabular}{|c|c|c|c|c|c|c|c|c|}
\hline $\begin{array}{l}\text { Children with disabilities should attend the } \\
\text { same schools as other children. }\end{array}$ & 287 & 49.9 & 12 & 2.1 & 273 & 47.5 & 3 & 0.5 \\
\hline $\begin{array}{l}\text { All children with disabilities should attend } \\
\text { special schools and not general mainstream } \\
\text { classes. }\end{array}$ & 510 & 88.7 & 7 & 1.2 & 53 & 9.2 & 5 & 0.9 \\
\hline $\begin{array}{l}\text { Schools are better prepared/equipped to deal } \\
\text { with children with disabilities than they were } \\
\text { ten years ago. }\end{array}$ & 519 & 90.3 & 20 & 3.5 & 18 & 3.1 & 18 & 3.1 \\
\hline $\begin{array}{l}\text { Children with disabilities should be } \\
\text { encouraged and supported to play with other } \\
\text { non-disabled children. }\end{array}$ & 454 & 79.0 & 18 & 3.1 & 98 & 17.0 & 5 & 0.9 \\
\hline $\begin{array}{l}\text { When children with disabilities leave school, } \\
\text { they have the same employment } \\
\text { opportunities as their peers. }\end{array}$ & 436 & 75.8 & 24 & 4.2 & 105 & 18.3 & 10 & 1.7 \\
\hline \multicolumn{9}{|c|}{ Statements regarding the protection of children with disabilities } \\
\hline $\begin{array}{l}\text { Children with disabilities are the subject of } \\
\text { jokes or unacceptable or negative comments. }\end{array}$ & 182 & 31.7 & 30 & 5.2 & 359 & 62.4 & 4 & 0.7 \\
\hline $\begin{array}{l}\text { Children with disabilities are more likely to } \\
\text { be the victims of bullying. }\end{array}$ & 344 & 59.8 & 26 & 4.5 & 201 & 35.0 & 4 & 0.7 \\
\hline $\begin{array}{l}\text { Children with disabilities are more } \\
\text { vulnerable to physical and sexual abuse. }\end{array}$ & 319 & 55.5 & 42 & 7.3 & 197 & 34.3 & 17 & 3.0 \\
\hline $\begin{array}{l}\text { Children with disabilities are more likely to } \\
\text { be neglected. }\end{array}$ & 260 & 45.2 & 24 & 4.2 & 288 & 50.1 & 3 & 0.5 \\
\hline $\begin{array}{l}\text { It is sometimes necessary to leave a child } \\
\text { with disabilities in the house alone. }\end{array}$ & 76 & 13.2 & 15 & 2.6 & 480 & 83.5 & 4 & 0.7 \\
\hline
\end{tabular}




\begin{tabular}{|l|l|l|l|l|l|l|l|l|}
\hline $\begin{array}{l}\text { It is sometimes necessary to punish a child } \\
\text { with disabilities for misbehaviour. }\end{array}$ & 196 & 34.1 & 23 & 4.0 & 352 & 61.2 & 4 & 0.7 \\
\hline
\end{tabular}

Table 5 Statistically significant differences in attitudinal responses by age

\begin{tabular}{|c|c|c|c|c|c|c|c|}
\hline \multirow[t]{2}{*}{ Statement } & \multirow[t]{2}{*}{ Response } & \multicolumn{2}{|c|}{$\begin{array}{l}\text { Under } \\
\text { years } \\
(n=254)\end{array}$} & \multicolumn{2}{|c|}{$\begin{array}{l}\text { 40-59 years } \\
(n=239)\end{array}$} & \multicolumn{2}{|c|}{$\begin{array}{l}60 \\
\text { and } a \\
(n=82)\end{array}$} \\
\hline & & No & $\%$ & No & $\%$ & No & $\%$ \\
\hline Attitudes $\quad$ towards & Agree & 219 & 86.2 & 224 & 93.7 & 72 & 87.8 \\
\hline $\begin{array}{l}\text { children with disabilities } \\
\text { are better than they were }\end{array}$ & $\begin{array}{l}\text { Neither agree } \\
\text { nor disagree }\end{array}$ & 15 & 5.9 & 9 & 3.8 & 8 & 9.8 \\
\hline $\begin{array}{l}\text { ten years ago. } \\
\text { Chi Sq. }=17.56(\mathrm{df}=6) \text {, }\end{array}$ & Disagree & 9 & 3.5 & 6 & 2.5 & 1 & 1.2 \\
\hline $\begin{array}{l}\mathrm{p}=.007431, \text { significant } \\
\text { at }<.01 .\end{array}$ & Don't know & 11 & 4.3 & 0 & 0 & 1 & 1.2 \\
\hline I would be happy to have & Agree & 135 & 53.2 & 127 & 53.1 & 33 & 40.2 \\
\hline $\begin{array}{l}\text { a family with a child } \\
\text { with disabilities living }\end{array}$ & $\begin{array}{l}\text { Neither agree } \\
\text { nor disagree }\end{array}$ & 10 & 3.9 & 7 & 2.9 & 8 & 9.8 \\
\hline next door to me. & Disagree & 103 & 40.6 & 102 & 42.7 & 41 & 50 \\
\hline $\begin{array}{l}\text { Chi Sq. }=12.76(\mathrm{df}=6), \\
\mathrm{p}=.047009, \text { significant }\end{array}$ & Don't know & 6 & 2.4 & 3 & 1.3 & 0 & 0 \\
\hline $\begin{array}{ll}\text { Children } & \text { with }\end{array}$ & Agree & 160 & 63.0 & 162 & 67.8 & 57 & 69.5 \\
\hline $\begin{array}{l}\text { disabilities make a } \\
\text { positive contribution to }\end{array}$ & $\begin{array}{l}\text { Neither agree } \\
\text { nor disagree }\end{array}$ & 32 & 12.6 & 30 & 12.6 & 5 & 6.1 \\
\hline the family. & Disagree & 49 & 19.3 & 44 & 18.4 & 20 & 24.4 \\
\hline
\end{tabular}




\begin{tabular}{|c|c|c|c|c|c|c|c|}
\hline $\begin{array}{l}\text { Chi Sq. }=13.55(\mathrm{df}=6), \\
\mathrm{p}=.035087, \text { significant } \\
\text { at }<.05 .\end{array}$ & Don't know & 13 & 5.1 & 3 & 1.3 & 0 & 0 \\
\hline $\begin{array}{l}\text { Schools are better } \\
\text { prepared and equipped }\end{array}$ & Agree & 223 & 87.8 & 222 & 92.9 & 74 & 90.2 \\
\hline $\begin{array}{l}\text { to deal with children } \\
\text { with disabilities than }\end{array}$ & $\begin{array}{l}\text { Neither agree } \\
\text { nor disagree }\end{array}$ & 11 & 4.3 & 2 & 0.8 & 7 & 8.5 \\
\hline $\begin{array}{l}\text { they were ten years ago. } \\
\text { Chi Sq. }=17.14(\mathrm{df}=6) \text {, }\end{array}$ & Disagree & 9 & 3.5 & 9 & 3.8 & 0 & 0 \\
\hline $\begin{array}{l}\mathrm{p}=.008782, \text { significant } \\
\text { at }<.01 .\end{array}$ & Don’t know & 11 & 4.3 & 6 & 2.5 & 1 & 1.2 \\
\hline $\begin{array}{ll}\text { Children } & \text { with }\end{array}$ & Agree & 69 & 27.2 & 76 & 31.8 & 37 & 45.1 \\
\hline $\begin{array}{l}\text { disabilities are the } \\
\text { subject of jokes or }\end{array}$ & $\begin{array}{l}\text { Neither agree } \\
\text { nor disagree }\end{array}$ & 16 & 6.3 & 7 & 2.9 & 7 & 8.5 \\
\hline $\begin{array}{l}\text { unacceptable or negative } \\
\text { comments. }\end{array}$ & Disagree & 166 & 65.4 & 156 & 65.3 & 38 & 46.3 \\
\hline $\begin{array}{l}\text { Chi Sq. }=16.77(\mathrm{df}=6) \text {, } \\
\mathrm{p}=.010167 \text {, significant } \\
\text { at }<.02 .\end{array}$ & Don't know & 3 & 1.2 & 1 & 0.4 & 0 & 0 \\
\hline \multirow{4}{*}{$\begin{array}{l}\text { Children with } \\
\text { disabilities are more } \\
\text { likely to be the victims } \\
\text { of bullying. }\end{array}$} & Agree & 160 & 63.0 & 140 & 58.6 & 44 & 53.7 \\
\hline & $\begin{array}{l}\text { Neither agree } \\
\text { nor disagree }\end{array}$ & 6 & 2.4 & 8 & 3.4 & 12 & 14.6 \\
\hline & Disagree & 86 & 33.9 & 90 & 37.7 & 25 & 30.5 \\
\hline & Don’t know & 2 & 0.8 & 1 & 0.4 & 1 & 1.2 \\
\hline
\end{tabular}




\begin{tabular}{|c|c|c|c|c|c|c|c|}
\hline $\begin{array}{l}\text { Chi Sq. }=24.58(\mathrm{df}=6), \\
\mathrm{p}=.000408, \text { significant } \\
\text { at }<.001 .\end{array}$ & & & & & & & \\
\hline $\begin{array}{ll}\text { Children } & \text { with } \\
\text { disabilities are more }\end{array}$ & Agree & 152 & 59.8 & 126 & 52.7 & 41 & 50.0 \\
\hline $\begin{array}{l}\text { vulnerable to physical } \\
\text { and sexual abuse. }\end{array}$ & $\begin{array}{l}\text { Neither agree } \\
\text { nor disagree }\end{array}$ & 17 & 6.7 & 14 & 5.9 & 11 & 13.4 \\
\hline $\begin{array}{l}\text { Chi Sq. }=12.95(\mathrm{df}=6), \\
\mathrm{p}=.043837 \text {, significant }\end{array}$ & Disagree & 76 & 29.9 & 95 & 39.6 & 26 & 31.7 \\
\hline at $<.05$ & Don't know & 9 & 3.5 & 4 & 1.7 & 4 & 4.9 \\
\hline
\end{tabular}


Table 6 Statistically significant differences in attitudinal responses by education level

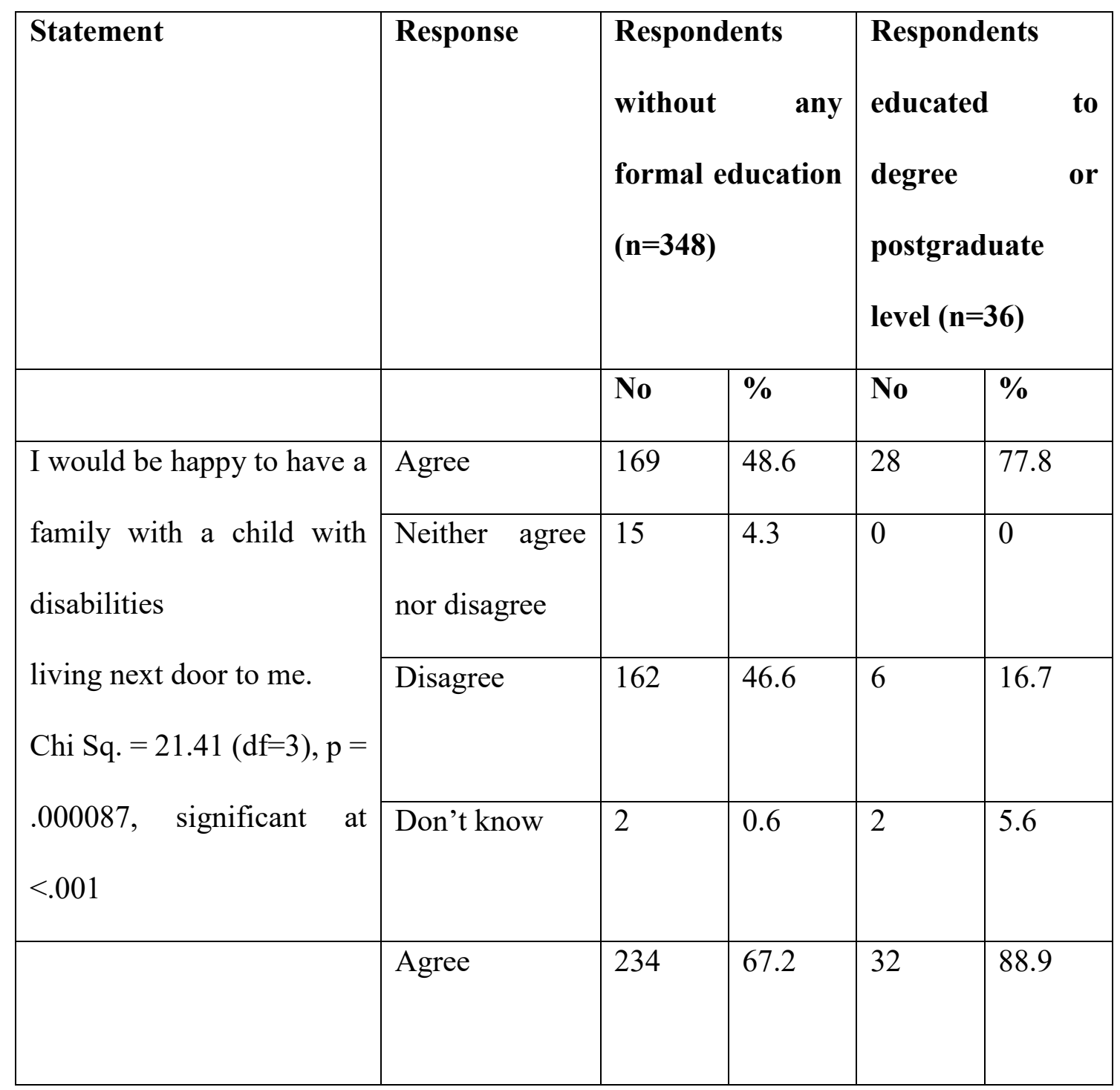




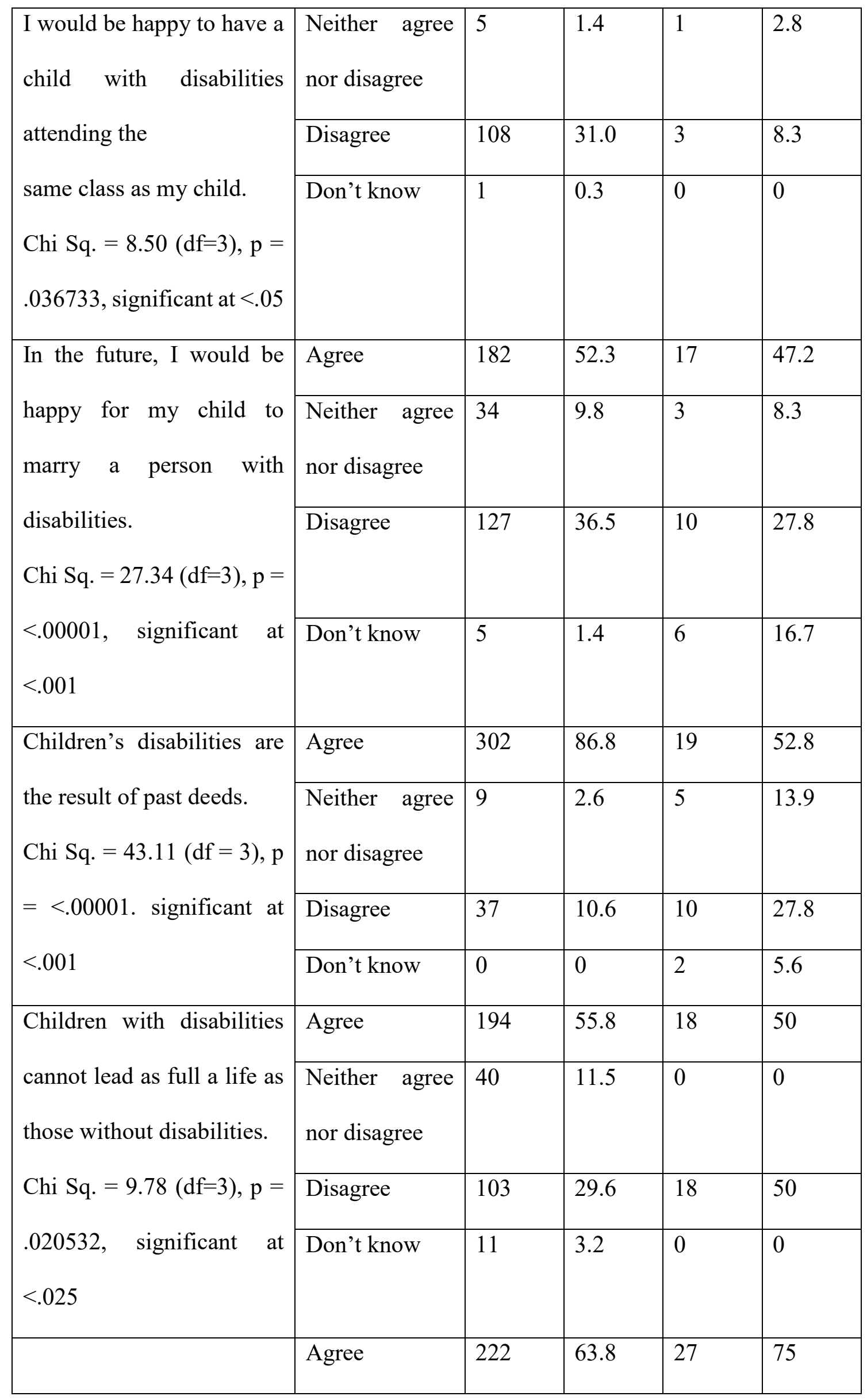




\begin{tabular}{|c|c|c|c|c|c|}
\hline $\begin{array}{l}\text { Children with disabilities } \\
\text { make } \quad \text { a }\end{array}$ & $\begin{array}{l}\text { Neither agree } \\
\text { nor disagree }\end{array}$ & 50 & 14.4 & 4 & 11.1 \\
\hline contribution to the family. & Disagree & 68 & 19.5 & 2 & 5.6 \\
\hline $\begin{array}{l}\text { Chi Sq. }=8.53(\mathrm{df}=3), \mathrm{p}= \\
.036239 \text {, significant at }<.05\end{array}$ & Don't know & 8 & 2.3 & 3 & 8.3 \\
\hline Children with disabilities & Agree & 192 & 55.2 & 30 & 83.3 \\
\hline $\begin{array}{l}\text { contribute to society. } \\
\text { Chi Sq. }=12.41(\mathrm{df}=3), \mathrm{p}=\end{array}$ & $\begin{array}{l}\text { Neither agree } \\
\text { nor disagree }\end{array}$ & 49 & 14.1 & 4 & 11.1 \\
\hline .006103 , significant at $<.01$ & Disagree & 92 & 26.4 & 1 & 2.8 \\
\hline & Don't know & 15 & 4.3 & 1 & 2.8 \\
\hline Schools are better & Agree & 317 & 91.1 & 25 & 69.4 \\
\hline $\begin{array}{l}\text { prepared/equipped to deal } \\
\text { with children with }\end{array}$ & $\begin{array}{l}\text { Neither agree } \\
\text { nor disagree }\end{array}$ & 11 & 3.2 & 4 & 11.1 \\
\hline disabilities than they were & Disagree & 7 & 2.0 & 6 & 16.7 \\
\hline $\begin{array}{l}\text { ten years ago. } \\
\text { Chi Sq. }=27.67(\mathrm{df}=3), \mathrm{p}= \\
<.00001, \text { significant at } \\
<.001 .\end{array}$ & Don't know & 12 & 3.5 & 1 & 2.8 \\
\hline Children with disabilities & Agree & 269 & 77.3 & 30 & 83.3 \\
\hline $\begin{array}{l}\text { should be encouraged and } \\
\text { supported to play with }\end{array}$ & $\begin{array}{l}\text { Neither agree } \\
\text { nor disagree }\end{array}$ & 8 & 2.3 & 4 & 11.1 \\
\hline other non-disabled & Disagree & 67 & 19.3 & 2 & 5.6 \\
\hline children. & Don’t know & 4 & 1.2 & 0 & 0 \\
\hline
\end{tabular}




\begin{tabular}{|l|l|l|l|l|l|}
\hline Chi Sq. $=12.08(\mathrm{df}=3), \mathrm{p}=$ & & & & & \\
$.007114, \quad$ significant at & & & & & \\
$<.01$. & & & & & \\
\hline
\end{tabular}

